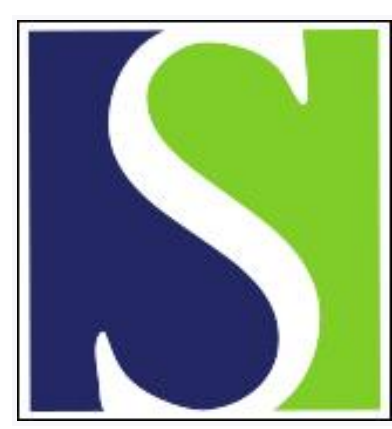

Scand J Work Environ Health 1997;23(2):114-120

https://doi.org/10.5271/sjweh.188

Issue date: Apr 1997

Terpene exposure and respiratory effects among workers in Swedish joinery shops

by Eriksson KA, Levin JO, Sandström T, Lindström-Espeling K, Lindén G, Stjernberg NL

Key terms: lung function; metabolite; monoterpene

This article in PubMed: www.ncbi.nlm.nih.gov/pubmed/9167234

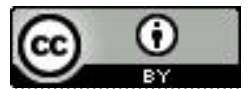




\title{
Terpene exposure and respiratory effects among workers in Swedish joinery shops
}

\author{
by Kåre A Eriksson, PhD, ${ }^{1,2,3}$ Jan O Levin, PhD, ${ }^{2}$ Thomas Sandström, MD, 2,4 \\ Karin Lindström-Espeling, MSc, ${ }^{1}$ Gerd Lindén, ${ }^{1}$ Nils L Stjernberg, MD ${ }^{2}$
}

\begin{abstract}
Eriksson KA, Levin J0, Sandström T, Lindström-Espeling K, Lindén G, Stjernberg NL. Terpene exposure and respiratory effects among workers in Swedish joinery shops. Scand J Work Environ Health 1997;23(2):114-20.
\end{abstract}

\begin{abstract}
Objectives Exposure to monoterpenes ( $\alpha$-pinene, $\beta$-pinene and $\Delta^{3}$-carene) in joinery shops was studied in Sweden during the processing of Scot's pine, and the acute respiratory effects among the employees were evaluated.

Methods A cross-sectional study of 38 workers was carried out in 4 joinery shops. The investigation included personal air sampling of monoterpenes, biological monitoring of metabolites of $\alpha$-pinene in the workers' urine, interviews following a standardized questionnaire, and dynamic spirometry.

Results The personal exposure to monoterpenes in the joinery shops was $10-214 \mathrm{mg} / \mathrm{m}^{3}$. The correlation (correlation coefficient $=0.69$ ) between exposure to $\alpha$-pinene and verbenols (metabolites from $\alpha$-pinene) in urine was relatively good. No acute effects on forced vital capacity or forced expiratory volume during $1 \mathrm{~s}$ were detected. The workers had significantly reduced preshift lung function values when compared with the values of a local reference group, even when smokers and ex-smokers were excluded.

Conclusions Personal exposure to the monoterpenes $\alpha$-pinene, $\beta$-pinene, and $\Delta^{3}$-carene in joinery shops may exceed the present Swedish occupational exposure limit of $150 \mathrm{mg} / \mathrm{m}^{3}$ during the winter season when workroom air is commonly recirculated. The determination of metabolites of $\alpha$-pinene (verbenols) in urine can be used as an index of exposure to fumes released during wood-treating processes. The results from the lung function tests indicate chronic rather than acute reactions in the airways. The fact that there were no major changes in lung function over a workshift indicates chronic reaction in the airways.
\end{abstract}

Key terms lung function, metabolites, monoterpenes.

The monoterpenes $\alpha$-pinene, $\beta$-pinene, and $\Delta^{3}$-carene are the main constituents of sawing fumes from Scot's pine (Pinus sylvestris) (1). These substances are irritating to skin and mucous membranes and can cause both allergic and nonallergic contact dermatitis (2-4). The occupational exposure limit in Sweden at present is $150 \mathrm{mg} / \mathrm{m}^{3}$ for both total and individual monoterpenes (5), and in sawmills the exposure often exceeds this limit $(1,6-7)$. Sawmill workers exposed to monoterpenes and wood dust have been shown to respond with airway symptoms, a decrease in lung function, and airway inflammation, the last-mentioned being reflected by bronchoalveolar lavage (BAL) results $(6-11)$. After the reduction of sawing fumes in a Swedish sawmill, an 8-year follow-up study was expected to show relative improvement in lung function among the employees working in the saw shed (12).

Pinewood is often handled in joinery shops, where various kinds of wooden products are manufactured. Common tasks in a joinery shop include planing, milling, sawing, drilling, and sanding. Although the wood has been dried, monoterpenes are released during these wood-treating processes. Since winters are cold in northern Sweden $\left(-10\right.$ to $\left.-30^{\circ} \mathrm{C}\right)$, most of the indoor air is often recirculated for energy-saving reasons. In joinery shops, the recirculated indoor air is passed through filters or a cyclone to minimize the content of wood dust before it is allowed to reenter the workshop. The content of

1 Department of Occupational and Environmental Medicine, University Hospital of Northern Sweden, Umeå, Sweden.

2 National Institute for Working Life, Umeå, Sweden.

3 Department of Environmental Technology and Work Sciences, Royal Institute of Technology, Stockholm, Sweden.

4 Department of Pulmonary Medicine and Allergology, University Hospital of Northern Sweden, Umeå, Sweden.

Reprint requests to: Dr KA Eriksson, Department of Occupational and Environmental Medicine, University Hospital of Northern Sweden, S-901 85 Umeå, Sweden. 
terpenes in used indoor air is not reduced to any large extent in the dust filters; therefore the concentration of terpenes can increase inside the workplace during the workday.

The assessment of personal exposure to monoterpenes can be performed by air sampling using charcoal tubes connected to a pump or by diffusive sampling (13-14). An attractive alternative to air sampling for exposure assessment is biological monitoring, as it takes into account ventilatory parameters and individual variability in absorption and metabolism, both of which influence the uptake or the absorption of a substance. We have therefore studied the metabolism of monoterpenes in humans and identified several metabolites of $\alpha$-pinene in the urine of exposed sawmill workers $(1,15)$. We also investigated the elimination kinetics of $(+)-$ and $(-)-\alpha-$ pinene as verbenols in humans after a single exposure for $2 \mathrm{~h}$ at 450,225 , and $10 \mathrm{mg} / \mathrm{m}^{3}$ in an exposure chamber (16). These investigations showed that verbenols can be detected in urine within $4 \mathrm{~h}$ after the end of the exposure at all 3 levels of exposure and up to $20 \mathrm{~h}$ after exposure at $450 \mathrm{mg} / \mathrm{m}^{3}$. The determination of verbenols in urine collected directly after the end of a workshift can thus be used to determine whether a person has been exposed to sawing fumes from pinewood during that day.

Exposure data on monoterpenes in joinery shops have not, to our knowledge, been presented earlier. The aim of the present study was to determine personal exposure to these substances in joinery shops with the use of air sampling and also the biological monitoring of verbenols in urine. A secondary objective was to study lung function and symptoms among the workers.

\section{Subjects and methods}

\section{Joinery shops}

Four joinery shops in northern Sweden, selected as representatives of joinery shops within the area, were investigated. They all handled pinewood (soft wood) but made different finished or semifinished products - outer and inner doors for family houses, window frames, strips of wood, and glue-laminated wood beams. The study was performed on 2 consecutive days at each shop, and the production of wooden goods followed normal practice at each workplace. The joinery shops recirculated the indoor air to an extent of approximately $80-100 \%$ since the outdoor temperature was approximately -10 to $-5^{\circ} \mathrm{C}$ when the investigations were performed.

The joinery shops all used room-dry wood (water content $8-10 \%$ weight/weight). The wood-treating processes included planing, sawing, cutting, milling, drilling, and sanding. The wood-treating machines, all furnished with exhaust devices, were located in the same room at each shop, except for the planer, which was generally located in a separate cabin, to reduce the workers' exposure to noise from this device.

The planks were transported to the planer by a conveyor onto which they were put automatically or manually. The planer operator's tasks included adjusting the planer according to the dimension of the planks to be treated and sweeping off shavings not sucked away from the machine by the exhaust equipment. Cleaning of the plane was done approximately 1 to 3 times per workshift, and the task was completed within 5 min on each occasion. After planing, the surfaced planks were picked manually from the moving belt leading from the planer and put onto a materials handling cart. When fully loaded, the cart was delivered to the sawyers, who cut the goods. The cut wood pieces were then milled, drilled, and finally sanded by workers operating these machines. In the mill producing glue-laminated wood beams, some of the workers were engaged in the task of putting wood beams together on an endless belt for dispatch into a gluing device. This gluing apparatus was located relatively far away from the wood-treating equipment.

\section{Subjects}

All of the workers in the joinery shops participated in the study, and consequently a total of 38 persons, 28 men and 10 women, mean age 40 (range $20-63$ ) years were examined. Of these subjects, 9 were current smokers, 9 were ex-smokers and 20 were never smokers. The exsmokers had stopped smoking 3-41 (mean 13) years before this investigation. None of the workers used any kind of personal breathing protection equipment.

\section{Exposure assessments}

Air sampling of monoterpenes and wood dust. Personal exposure to monoterpenes was assessed by diffusive sampling with charcoal (SKC 530-04, Eighty Four, Pennsylvania, United States) as sorbent. The sampler (SKC 530-16) was attached to the lapel of the worker's overalls, and the sampling period was $7-8 \mathrm{~h}$. The samplers were kept at $-20^{\circ} \mathrm{C}$ ( $2-7$ days) until analysis by gas chromatography, using a capillary column with an nonpolar phase. The analytical procedure has been described in detail elsewhere (1).

Exposure to wood dust was measured by pumped personal sampling (SKC 224-PCXR7), using the 37-mm open-face cassette method with an airflow of $21 / \mathrm{min}$, the sampling time being approximately $8 \mathrm{~h}$. The filters were conditioned for 16 hours at $21 \pm 0.5^{\circ} \mathrm{C}$ and at a relative humidity of $55 \pm 2 \%$ and were weighed before and after the sampling period.

Biological monitoring. Urine samples were collected before and immediately after the workshift. The urine was 
kept at $-20^{\circ} \mathrm{C}$ until analysis, which was carried out within 2 months after the sampling. After enzymatic hydrolysis and cleaning of the samples by solid phase extraction, the amount of verbenols in the urine was determined by gas chromatography. The analytical method used has been described earlier (1).

\section{Lung function tests}

Measurements of pulmonary function were carried out with a spirometer (Vitalograph-Compact ${ }^{\circledR}$ ) in the morning immediately before work was started and directly after the end of the workshift. The spirometer was calibrated before the first measurement was performed, after 3 persons had carried out spirometry, and at the end of the day of investigation after the latest person had performed the test. Forced vital capacity (FVC) and forced expiratory volume during $1 \mathrm{~s}\left(\mathrm{FEV}_{1.0}\right)$ were recorded by the same test. Forced expiratory flow $\left(\mathrm{FEF}_{75}\right)$ was obtained from the curve at the point where $75 \%$ of the FVC had been expired. This parameter was used to reflect flow changes in small airways. At least 3 readings with a maximal tolerated difference of $5 \%$ between the highest and next highest value of the FVC and $\mathrm{FEV}_{1.0}$ were obtained with the subject sitting down and wearing a nose clip. According to criteria of the American Thoracic Society (17), the best examination was chosen for the analysis. Lung function tests were performed on 38 workers. All air volumes are given at body temperature and pressure saturated (BTPS). In the calculations of the lung function values as the percentage of predicted values, local reference values were used (to be published). A population of 579 healthy persons was randomly selected (quota sample) from the local population register of Umeå. The population selected was evenly distributed between persons 20 and 59 years of age, as reference values for a working population were needed. The material was balanced between respective 10-year age groups, with approximately 70 persons in each group. Altogether 459 subjects (239 women and 220 men) filled out a questionnaire concerning respiratory symptoms, and they were invited to undergo a lung function test and a health examination, carried out by an experienced physician. Thirty-nine subjects declined to participate, and 3 were excluded because of unsatisfactory test performances, leaving a total of 417 adequately performed lung function tests. On the basis of answers to the questionnaire, smoking data, medical history, and the results of the physical examination, a group of 217 nonsmoking subjects ( 99 men, 118 women) remained. Regression lines were fitted for a large number of lung function variables, including those used in this study.

\section{Questionnaire}

Questions regarding acute symptoms were answered by all the subjects immediately before and after a workshift. They had been chosen according to a standardized questionnaire. The questions pertained to headache, dizziness, tiredness, chest tightness, cough, dyspnea, irritation of the eyes, nose, or throat. The intensity of the symptoms was determined according to Borg's scale (18).

\section{Statistics}

In interpreting results from the lung function readings and the questionnaires, the Wilcoxon signed rank test for paired observations was used. Spearman's rank correlation test was used for correlation testing. A P-value of $<0.05$ was considered significant.

\section{Results}

\section{Monoterpene and wood dust concentrations}

In table 1, the exposure to total terpenes and wood dust is given for the workers at the respective joinery shop. The geometric mean (GM) of the personal exposure to total terpenes during a workshift at the different joinery shops was $19-123 \mathrm{mg} / \mathrm{m}^{3}$. The exposure to terpenes

Table 1. Level of exposure to terpenes, wood dust and verbenols in the different joinery shops studied.

\begin{tabular}{|c|c|c|c|c|c|c|c|c|c|c|c|c|c|}
\hline \multirow{3}{*}{$\begin{array}{l}\text { Type of } \\
\text { joinery shop }\end{array}$} & \multirow{3}{*}{$\begin{array}{c}\text { Number } \\
\text { of } \\
\text { workers }\end{array}$} & \multicolumn{3}{|c|}{ Total terpenes $\left(\mathrm{mg} / \mathrm{m}^{3}\right)$} & \multicolumn{3}{|c|}{ Wood dust (mg/m³) } & \multicolumn{6}{|c|}{ Verbenols ( $\mu \mathrm{mol} / \mathrm{mmol}$ creatinine) } \\
\hline & & \multirow{2}{*}{$\begin{array}{l}\text { Geo- } \\
\text { metric } \\
\text { mean }\end{array}$} & \multirow{2}{*}{$\begin{array}{l}\text { Arith- } \\
\text { metic } \\
\text { mean }\end{array}$} & \multirow[t]{2}{*}{ Range } & \multirow{2}{*}{$\begin{array}{l}\text { Geo- } \\
\text { metric } \\
\text { mean }\end{array}$} & \multirow{2}{*}{$\begin{array}{l}\text { Arith- } \\
\text { metic } \\
\text { mean }\end{array}$} & \multirow[t]{2}{*}{ Range } & \multicolumn{3}{|c|}{ Preshift urine } & \multicolumn{3}{|c|}{ Postshift urine } \\
\hline & & & & & & & & $\begin{array}{c}\text { Geo- } \\
\text { metric } \\
\text { mean }\end{array}$ & $\begin{array}{l}\text { Arith- } \\
\text { metic } \\
\text { mean }\end{array}$ & Range & $\begin{array}{l}\text { Geo- } \\
\text { metric } \\
\text { mean }\end{array}$ & $\begin{array}{l}\text { Arith- } \\
\text { metic } \\
\text { mean }\end{array}$ & Range \\
\hline Doors & 10 & 19 & 21 & $9-33$ & 0.9 & 1.2 & $0.2-4.6$ & 0.33 & 0.40 & $0.12-0.87$ & 5.3 & 5.83 & $2.2-8.8$ \\
\hline Strips of wood & 9 & 35 & 36 & $27-47$ & $0.3^{\mathrm{a}}$ & 0.3 & $0.1-0.5$ & 1.15 & 1.23 & $0.65-1.97$ & 4.4 & 5.13 & $2.6-7.7$ \\
\hline Window frames & 9 & 41 & 45 & $15-79$ & 0.3 & 0.4 & $0.2-1.0$ & 1.00 & 1.45 & $0.23-4.97$ & 5.6 & 8.96 & $0.6-20.6$ \\
\hline $\begin{array}{l}\text { Glue-laminated } \\
\text { wood beams }\end{array}$ & 10 & 123 & 135 & $38-214$ & 0.4 & 0.4 & $0.3-0.5$ & 4.34 & 6.54 & $0.81-27.5$ & 36,1 & 45.0 & $20.2-101$ \\
\hline All & 38 & 43 & 60 & $9-214$ & 0.4 & 0.6 & $0.1-4.6$ & 1.14 & 2.43 & $0.12-27.5$ & 9,12 & 16.5 & $0.6-101$ \\
\hline
\end{tabular}

a Number of samples $=7$. 
was highest at the joinery shop producing glue-laminated wood beams. For some of the workers in this joinery shop, the time-weighted personal exposure exceeded the present Swedish limit of $150 \mathrm{mg} / \mathrm{m}^{3}$ for total terpenes. The exposure to wood dust was relatively low (GM $0.3-0.9 \mathrm{mg} / \mathrm{m}^{3}$ ) in each joinery shop, compared with the present Swedish exposure limit of $2 \mathrm{mg} / \mathrm{m}^{3}$. One worker at the joinery shop producing doors was subject to an exposure of $4.6 \mathrm{mg} / \mathrm{m}^{3}$ during the workshift (table 1). He had to repair the planer during approximately $3 \mathrm{~h}$ and used compressed air to blow away wood shavings from the device. This event may explain his relatively high exposure to wood dust on the day of the investigation.

\section{Biological monitoring}

Table 1 also shows the concentration of verbenols in the pre- and postshift urine samples from the exposed workers. Verbenols in preshift urine were quantified for each worker. In general, the concentration of verbenols in the postshift urine samples was higher when compared with the concentration in the preshift samples. Figure 1 illustrates the correlation between the mean personal exposure to $\alpha$-pinene during a workday and the concentration of verbenols in urine after the end of the workshift. The coefficient of correlation was 0.69 .

\section{Lung function parameters}

The preshift lung function values and percentage of change over the workshift are given in table 2 for all 38 workers and the 20 never smokers. The general trend for the preshift lung function parameters was that they were lower than the age-matched normal values based upon a randomized sample of the local nonsmoking population $(\mathrm{P}=0.07-<0.001)$ (table 2). The $\mathrm{FEF}_{75}$ was no longer significantly decreased when the 18 current smokers and ex-smokers were excluded. This result for the smokers indicates that this common finding, representing an involvement of the small airways, was indeed smoke-re-

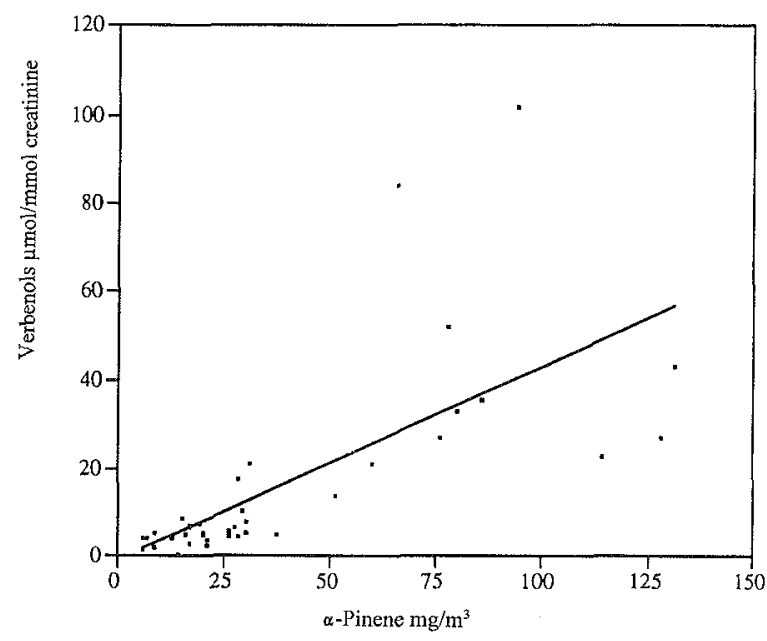

Figure 1. Correlation between verbenols (umol/mmol creatinine) in postshift urine samples and average $\alpha$-pinene exposure $\left(\mathrm{mg} / \mathrm{m}^{3}\right)$ during a workshift among 38 persons at 4 joinery shops (regression line: $y=-0.65+0.44 x$; correlation coefficient $=0.69$ ).

lated (table 2). In contrast, the tendency toward a low vital capacity (VC) remained in the comparison with the reference population $(\mathrm{P}=0.06)$, as did the significantly low $\mathrm{FEV}_{1.0}$ and $\mathrm{FEV}_{1.0} / \mathrm{VC}(\mathrm{P}<0.01$ and $\mathrm{P}<0.05$, respectively). Neither for the whole group of 38 workers nor for the group of 20 never smokers were there any significant changes in any of the lung function parameters over a workshift. There was no correlation between exposure to terpenes during a workshift and acute changes in any of the lung function parameters studied.

\section{Acute subjective symptoms}

The absolute prevalence values of acute preshift subjective symptoms were as follows. Two subjects experienced eyes, nose, and throat irritation, whereas 2 workers experienced eye irritation, 2 felt nose irritation, and 2 observed throat irritation. In general, there was no statistically significant change in any of the recorded symptoms over a workshift.

Table 2. Preshift lung function parameters of 38 employees (including smokers and ex-smokers) and the 20 never smokers in the joinery shops as the percentage of reference values and the percentage of change over a workshift. (VC = vital capacity, FVC = forced vital capacity, $\mathrm{FEV}_{1.0}=$ forced vital capacity in $1 \mathrm{~s}, \mathrm{FEF}_{75}=$ forced expiratory flow rate at $75 \%$ of the $\mathrm{FVC}$ )

\begin{tabular}{|c|c|c|c|c|c|c|c|c|}
\hline \multirow[t]{3}{*}{ Lung function parameters } & \multicolumn{4}{|c|}{38 workers } & \multicolumn{4}{|c|}{20 never smokers } \\
\hline & \multicolumn{2}{|c|}{$\begin{array}{l}\text { Percentage of } \\
\text { reference values }\end{array}$} & \multicolumn{2}{|c|}{$\begin{array}{c}\text { Percentage of change } \\
\text { over work shift }\end{array}$} & \multicolumn{2}{|c|}{$\begin{array}{l}\text { Percentage of } \\
\text { reference values }\end{array}$} & \multicolumn{2}{|c|}{$\begin{array}{l}\text { Percentage of change } \\
\text { over workshift }\end{array}$} \\
\hline & Mean & SD & Mean & SD & Mean & $\mathrm{SD}$ & Mean & SD \\
\hline $\begin{array}{l}\text { VC } \\
\mathrm{FVC} \\
\mathrm{FEV}_{1.0} \\
\mathrm{FEV}_{1.0} \mathrm{NC} \\
\mathrm{FEV}_{75}\end{array}$ & $\begin{array}{l}96.5 \\
96.1 \\
89.9 \\
92.9 \\
84.0\end{array}$ & $\begin{array}{l}13.8^{a} \\
14.8^{a} \\
15.3^{\star \star \star} \\
10.0^{\star \star \star} \\
34.0^{\star \star}\end{array}$ & $\begin{array}{l}3.8 \\
1.8 \\
2.3 \\
0.7 \\
2.8\end{array}$ & $\begin{array}{r}8.7 \\
10.3 \\
8.8 \\
5.7 \\
22.9\end{array}$ & $\begin{array}{l}95.0 \\
95.4 \\
90.3 \\
94.8 \\
90.1\end{array}$ & $\begin{array}{c}9.9^{\circ} \\
10.2^{\circ} \\
13.0^{* \star} \\
9.8^{*} \\
39.4\end{array}$ & $\begin{array}{l}3.3 \\
2.3 \\
3.3 \\
0.2 \\
7.1\end{array}$ & $\begin{array}{r}9.0 \\
9.5 \\
8.6 \\
4.3 \\
25.8\end{array}$ \\
\hline
\end{tabular}

${ }^{*} P<0.05,{ }^{* *} P<0.01,{ }^{* * *} P<0.001,{ }^{a} P=0.07, b P=0.06$ 


\section{Discussion}

Our report is, to our knowledge, the first to present exposure to terpenes in joinery shops. The personal exposure to terpenes during a workshift at the joinery shops was between 9 and $214 \mathrm{mg} / \mathrm{m}^{3}$ (table 1), and the exposure was highest in the shop producing glue-laminated wood beams. For 3 of the workers in this shop, the Swedish exposure limit of $150 \mathrm{mg} / \mathrm{m}^{3}$ was exceeded during the day of investigation. The workers who glued wood beams had almost the same degree of exposure to monoterpenes as the workers performing wood-treating tasks, even though the gluing device was situated relatively far away from the wood-treating machinery. The production of glue-laminated wood beams and window frames consumed relatively large quantities of wood when compared with the mass of wood used in the production of strips and doors. The operations of planing, sawing, cutting, milling, and sanding were performed during the whole workshift in the production of glue-laminated wood beams. At the other joinery shops the dominating treatment of the wood was planing, while a relatively small portion of the work was sawing, cutting, milling, drilling and sanding.

Dust and sawing fumes released during wood-treating operations may contaminate the work environment if not effectively eliminated by exhaust equipment. In the joinery shops studied, all the machinery was provided with exhaust equipment. However, the indoor air, including the air captured by the ventilation equipment attached to the machinery, was recirculated during the workday. The concentration of monoterpenes in the recirculated air probably did not decrease during the dustcleaning process, as the air was passed only through dust filters or a cyclone, and not through a charcoal sieve or filters with other types of adsorbents onto which these substances may have been trapped.

The relatively high exposures to terpenes in the workshop producing glue-laminated wood beams in contrast to the situation in the other shops may thus be explained by the release of relatively high levels of monoterpenes from intense wood-treating processes and the recirculation of indoor air.

We also studied the question of whether the determination of verbenols in workers' urine after the end of a workshift could be used as a method for evaluating personal exposure to sawing fumes. Figure 1 shows that the higher the $\alpha$-pinene exposure during the day, the higher the concentration of verbenols in the postshift urine (correlation coefficient $=0.69$ ). As shown in figure 1 , some points deviate appreciably from the regression line. The distribution at the higher exposure end of the curve can probably be explained to some extent by the role of different work practices and inhalation rates. Verbenols were quantified in urine samples collected from every worker before the workshift (table 1). The detection of these substances in the morning urine indicated that $\alpha$ pinene or cis- and trans-verbenol or both were retained in the human body after exposure to monoterpenes 1 to 2 days before the day of investigation. According to Falk et al (19), experimental exposure of humans to $\alpha$-pinene in an exposure chamber for $2 \mathrm{~h}$ showed that this monoterpene had a long half-time in poorly perfused tissues. The authors concluded that it would take more than 2 days for the body to be almost completely cleared of $\alpha$-pinene after a single exposure for $2 \mathrm{~h}$. Thus exposure to monoterpenes during consecutive workshifts may give rise to a body burden of $\alpha$-pinene in humans, as this substance may accumulate in tissues rich in fat. Our excretion data from the kinetic study showed the existence of 2 rate constants for the elimination of $\alpha$-pinene as verbenols in urine from the human body. The elimination half-times were 0.6 and $6 \mathrm{~h}$, respectively (15). Thus the elimination half-time of $6 \mathrm{~h}$ indicated that some of the inhaled $\alpha$-pinene was retained in the human body after exposure to this substance. Consequently, there was probably a contribution of verbenols in the postshift urine owing to the excretion of accumulated $\alpha$-pinene, as the workers had been exposed to monoterpenes 1 to 2 days before the study was conducted. We have not corrected for this contribution when calculating correlations between $\alpha$-pinene in air and urinary verbenol. Biotransformation is different for different people and the biological half-time (ie, the excretion velocities of metabolites) may vary between persons. In addition, dietary factors and smoking habits may also affect the excretion of xenobiotica. We have recently performed air sampling of monoterpenes and determined the concentration of verbenols in postshift urine among sawmill workers (7). The coefficient of correlation between the concentration of verbenols in the postshift urine and the personal exposure to terpenes during a workday in that study was 0.84 . We conclude that the determination of verbenols in urine can be used as a biological exposure index (BEI) and a $\mathrm{BEI}$ of $60 \mu \mathrm{mol} / \mathrm{mmol}$ creatinine for terpenes is suggested. However, the urine samples should be collected directly after the end of exposure because of the relatively short excretion half-time of 0.6 hours.

In addition, since $\alpha$-pinene is present in turpentine from every pine species in the world - with a few exceptions (20), it is our opinion that the quantification of verbenols in postshift urine can be used as a tool to determine the personal exposure to sawing fumes from pine in general.

In joinery shops, the determination of verbenols in urine can be used to evaluate whether measures taken to reduce personal exposure to sawing fumes have been effective or not. If the level of a-pinene in the workplace atmosphere is reduced, it is likely that a decrease would also occur in the concentration of verbenols in the work- 
ers' urine as the amount of a-pinene inhaled is decreased. However, the usefulness of determining verbenols in workers' urine for studying the effectiveness of technical improvements in reducing the personal exposure to sawing fumes should be evaluated in future studies.

The workers did not demonstrate any significant changes in lung function over a workshift. In contrast, the workers had significantly lower preshift lung function values as compared with the local reference values based upon a large cohort of healthy subjects randomly selected from the same area. The lung function data still remained significantly low when smokers and ex-smokers were excluded, and therefore smoking was not the confounding factor. The lung function reduction was more pronounced in terms of airflow $\left(\mathrm{FEV}_{1,0}\right)$ than in terms of a possibly restrictive pattern (VC). Consequently, the ratio $\mathrm{FEV}_{1.0} / \mathrm{VC}$ was significantly lower for the joinery shop workers than for the reference population, and therefore indicated an obstructive lung function pattern. This is an interesting observation since no asthmatics were included in the study, and also manual workers commonly have supernormal lung function values and a "healthy worker effect" is often a confounding factor. It is also interesting that the sawmill workers in an earlier study were not found to have low $\mathrm{FEV}_{1.0} / \mathrm{VC}$ (7). The lung function observations in this study were interpreted as a possible response to a long-term irritative effect of sawing fumes and/or saw dust released during the wood-treating operations in the joinery shops. The fact that there were no major changes in lung function over the workshifts indicates chronic rather than acute reactions in the airways.

No significant changes in subjective symptoms were reported by the joinery shop workers in contrast to the recently reported, statistically significant increase in eye irritation during a workshift among sawmill workers (7). The exposure to monoterpenes and wood dust was approximately the same within the sawmills and the joinery shops studied. Fresh wood is handled in sawmills. Sawing of fresh wood releases water-soluble substances, such as aldehydes and carboxylic acids ("unpublished observations"), which may dissolve in the mucous membranes of the eyes and thus cause an irritative effect. The wood is dried to reduce the water content to approximately 8 $10 \%$ (weight/weight) to make it suitable for joinery shop work. During the drying process it is likely that the content of water-soluble substances is also reduced in the planks. The emission of water-soluble substances from the planks during wood-treating processes may thus be lower than that during the sawing of fresh wood. This possibility could explain the difference in reported eye irritation among the sawmill workers and employees in the joinery shops studied. However, exposure to aldehydes, carboxylic acids, and other strongly irritating substances released from wood in sawmills and joinery shops may have been of importance, an aspect which needs to be evaluated in future studies.

It is concluded that the personal exposure to terpenes in joinery shops may exceed the present Swedish occupational exposure limit of $150 \mathrm{mg} / \mathrm{m}^{3}$. Recirculation of indoor air is the probable cause. Determination of verbenols in urine can be used as an exposure index to fumes released during wood-treating processes. No acute changes in lung function parameters were observed during a workshift, but the joinery shop workers had significantly lower lung function than local referents, even when smokers and ex-smokers were excluded.

\section{Acknowledgments}

Financial grants from the Department of Occupational and Environmental Medicine, University Hospital of Northern Sweden, Umeå, Sweden, and the National Institute for Working Life, Umeå, Sweden, are gratefully acknowledged.

The skillful technical assistance provided by Ms Anna Wenngren and Ms Annika Hagenbjörk-Gustafsson is gratefully acknowledged. Ulf Hammarström is gratefully acknowledged for the statistical calculations. MajCari Ledin is gratefully acknowledged for supplying lung function data from the reference population.

\section{References}

1. Eriksson K, Levin J-O. Identification of cis-and trans-verbenol in human urine after occupational exposure to terpenes. Int Arch Occup Environ Health 1990;62:379—83.

2. Grimm W, Gries H. Turpentine. In: Parmeggiani L, editor. Encyclopaedia of occupational safety and health. Geneva: International Labour Organisation 1983:2229.

3. Hellerström S. Hypersensitivity tests in professional eczema and their applicability and sources of error [discussion]. Acta Dermatal Venereol 1939;20:657.

4. Pirilä V, Siltanen E. On the chemical nature of the eczematogenic agent in oil of turpentine III. Dermatologica 1958; $117: 1-8$.

5. National Swedish Board of Occupational Safety and Health (NSBOSH). Hygieniska grănsvården [Occupational exposure limit]. Stockholm: NSBOSH, 1993. Ordinance AFS 1993:9.

6. Hedenstierna G, Alexandersson R, Wimander K, Rosén G. Exposure to terpenes: effects on pulmonary function. Int Arch Occup Environ Health 1983;51:191-8.

7. Eriksson KA, Stjernberg NL, Levin JO, Hammarström U, Ledin MC. Terpene exposure and respiratory effects among sawmill workers. Scand J Work Environ Health 1996;22: 182-90.

8. Goldsmith DF, Shy CM. Respiratory health effects from occupational exposure to wood dusts. Scand J Work Environ Health 1988:14:1-15.

9. Malo J-L, Cartier A, Boulet L-P. Occupational asthma in sawmills of eastern Canada and United States. J Allergy Clin 
Immunol 1986;78:392 - 8.

10. Enarson D, Chan-Yeung M. Characterization of health effects of wood dust exposures. Am J Ind Med 1990;17:33 - 8.

11. Johard U, Eklund A, Dahlqvist M, Ahlander A, Alexandersson R, Ekholm U, et al. Signs of alveolar inflammation in nonsmoking Swedish wood trimmers. Br J Ind Med 1992;49: 428-34

12. Dahlqvist M, Alexandersson R, Ulfvarsson U. Pulmonary function changes in sawmill workers - a prospective study of occupational exposure to sawfumes. Occup Hyg 1994;1:1726.

13. Eriksson K, Levin J-O, Rhén M, Lindahl R. Evaluation of a diffusive sampler for air sampling of monoterpenes. Analyst 1994;119:85-8.

14. Eriksson $\mathrm{K}$, Levin $\mathbf{J}-\mathrm{O}$, Field validation of a diffusive sampler for the assessment of personal exposure to sawing fumes. Chemosphere 1995;30:1541—9.

15. Eriksson K, Levin J-O. Gas chromatographic - mass spectrometric identification of metabolites from $\alpha$-pinene in human urine after occupational exposure to sawing fumes. J Chromatogr B 1996;677:85-98.

16. Levin J-O, Eriksson K, Falk A, Löf A. Renal elimination of verbenols in man following experimental $\alpha$-pinene inhalation exposure. Int Arch Occup Environ Health 1992;63:571-3.

17. Anonymous. ATS statement-snowbird workshop on standardization of spirometry. Am Rev Respir Dis 1979;119:831-8.

18. Borg G. Psychophysical bases of perceived exertion. Med Sci Sports Excerc 1982;14:377-81.

19. Falk AA, Hagberg MT, Löf AE, Wigaeus-Hjelm EM, Zhiping W. Uptake, distribution and elimination of $\alpha$-pinene in man after exposure by inhalation. Scand J Work Environ Health 1990;16:372-8.

20. Mirov NT. Composition of gum turpentine of pines. Washing ton (DC): US Department of Agriculture, Forest Service, 1961. Technical bulletin, no 1239 .

Received for publication: 3 June 1996 